\title{
A I4-24 ÉV KÖZÖTTI FIATALOK SZERENCSEJÁTÉK-HASZNÁLATI KOCKÁZATÁNAK CSÖKKENTÉSÉRE IRÁNYULÓ ÁLTALÁNOS PREVENCIÓS PROGRAMOK SZISZTEMATIKUS ÁTTEKINTÉSE
}

\author{
MAGI ANNA \\ ELTE PPK Pszichológiai Intézet \\ ELTE PPK Pszichológiai Doktori Iskola
}

\begin{abstract}
A tanulmány az értékelt iskolai univerzális prevenciós programok irodalmát összegzi. 3 releváns adatbázis körében, a kérdést megjelenítő kereső algoritmus alapján 8 általános prevenciós program 9 értékelése kerül bemutatásra. Négy közbülső célt azonosítottunk, melyek a (problémás) szerencsejáték használattal kapcsolatban kedvező irányú változást idéztek elő: 1) ismeretátadás; 2) hiedelmek lebontása; 3) attitűdök befolyásolása; 4) készségfejlesztés. Az értékelt programok egy-vagy többüléses intervenciók, tartalmaznak interaktív és/vagy multimédiás elemeket, egy kivételével mindegyik eszköztárában szerepel frontális előadás. Eredményeink a szerencsejáték használat kockázatainak csökkentésére a komplex programok alkalmazását javasolják.
\end{abstract}

Kulcsszavakः szerencsejáték használat, problémás szerencsejáték használat, univerzális prevenció, prevenciós célok, prevenciós eszközök, prevenciós programok értékelése

Current study is a systematic review of the existing literature about the effective universal gambling prevention programs for youth between the age of 14-24. Altogether 9 evaluation studies of 8 universal gambling prevention programs were evaluated retrieved from 3 databases with an appropriate search algorithm. We identified 4 main intermediate aims that induced positive changes in connection with (problematic) gambling: 1) providing information; 2) decrease biased beliefs; 3) modify attitudes; 4) skill improvement. Among the retrieved studies there are interventions with one to several sessions. All but one program applied frontal lectures, supplemented with interactive elements or multi-

Levelező szerző: Magi Anna, ELTE PPK Pszichológiai Intézet, 1064 Budapest, Izabella utca 46.

E-mail cím: magi.anna@ppk.elte.hu 
media tools. Our results points toward the effectiveness of complex universal gambling prevention programs both in terms of their aims and methods.

Keywords: gambling, problematic gambling, universal prevention, prevention aims, prevention tools

\section{Bevezetés}

A függőség olyan viselkedés, amely felett a személy nem képes kontrollt gyakorolni, kényszeresen ismétli, és ártalmas saját magára és/vagy a környezetére nézve (Demetrovics 2007). ${ }^{1}$ A viselkedési függőségek esetében a cselekvések középpontjában nem kémiai szer, hanem adott viselkedés áll. A szerhez köthető és a viselkedéses addikciók között egyik legnagyobb eltérés, hogy míg a kémiai szerek esetében szinte soha nem beszélhetünk egészséges szintről, addig a viselkedési függőségek olyan cselekvések esetében is azonosíthatók, melyek bizonyos mértékben a mindennapi élet velejárói, akár az egészséges életmód részei is lehetnek ( $\mathrm{pl}$. munka vagy testedzés). A szerencsejáték-használatnak, ahogy magának a játéknak is, a kikapcsolódásban és a szórakozásban lehet szerepe, zavarról abban az esetben beszélhetünk, ha ez túlzott mértéket ölt és funkcióromlást okoz.

A nemzetközileg elfogadott nomenklatúrákban (pl. Betegségek Nemzetközi Osztályozásának 10. kiadása, World Healtb Organization 1992; vagy a Diagnostic and Statistical Manual of Mental Disorders korábbi, 4. átdolgozott kiadása, American Psychiatric Association [APA] 2000) a nem szerhez köthető addikciós problémákat az impulzuskontroll-zavarok körében említik. Az első addikciós zavarként elismert, nem kémiai szerhez köthető szenvedélybetegség a szerencsejáték-használati zavar (APA 2013; korábban: patológiás szerencsejáték-használat, APA 2000).

Néhány, az utóbbi évtizedben készült kutatási adat (Paksi-Magi-Demetrovics 2015; Demetrovics et al. 2016) alapján Magyarországon a 18-64 éves népesség több mint fele (52,3-57,4\%) játszott már valaha életében szerencsejátékkal. A problémás szerencsejáték-használat kockázatának megállapítására több eszköz is rendelkezésünkre áll, az egyik legelterjedtebb a már magyarul is elérhető Szerencsejáték Probléma Súlyossága Kérdőiv (PGSI-HU; Problem Gambling Severity Index - Hungarian, Gyollai et al. 2013). Ezen eszköz segítségével a legfrissebb kutatások (Paksi-Magi-Demetrovics 2015; Demetrovics et al. 2016) a felnőtt magyar lakosság 2,2-3,1\%-át azonosították alacsony problémájú játékosként, a közepes mértékü problémát mutató csoport aránya 1,1-2,3\% között mozog, a kifejezetten problémás játékosok arányát pedig 0,8 és 1,0\% közé becsülik.

Bár Magyarországon a törvényi szabályozás (1991. évi XXXIV. törvény) tiltja a 18 év alattiak számára a szerencsejátékok használatát, a kutatások magas mértékủ érintett-

Támogató: A tanulmány a Szerencsejáték Zrt. Társadalmi felelősségvállalási programjának finanszírozásával készült, „A fiatal 14-24 év közötti populáció körében tervezett, a szerencsejáték tevékenység kockázatainak csökkentésére irányuló prevenciós tevékenység szakmai megalapozása" címü kutatás keretében. A kutatás vezetői: Demetrovics Zsolt (ELTE PPK Pszichológiai Intézet), Paksi Borbála (ELTE PPK Neveléstudományi Intézet). Közreműködő: Kó József(Országos Kriminológiai Intézet). 


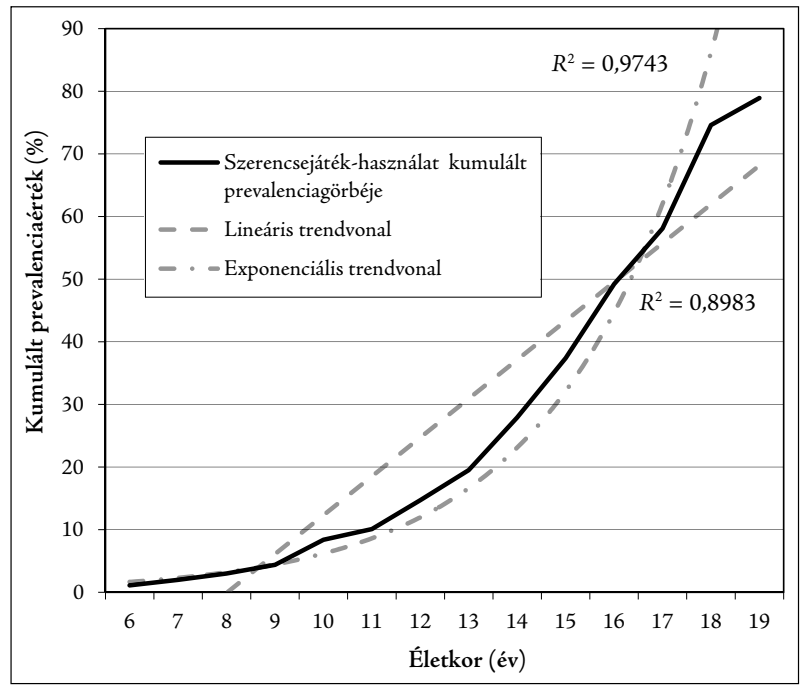

1. ábra: A szerencsejátékokkal való kapcsolatba kerülés kockázata különböző korévekben a 7-14. évfolyamos diákok körében $(N=2872)(\%)$ (Paksi-Magi-Demetrovics 2016)

séget jeleznek a 18 év alatti populációban is, például a 7-14. évfolyamos diákok körében a szerencsejáték-használat életprevalencia-értéke 58\% (Paksi-Magi-Demetrovics 2016). A vizsgálat a minta 9,6\%-a esetében azonosította a probléma kockázatának alacsony, 5,9\%-uknál pedig közepes mértékét. A kifejezetten problémás játékosok aránya pedig $2,1 \%$ volt az említett vizsgálatban. Ha ezeket az eredményeket összevetjük az időben legközelebb eső, felnőtt lakosság reprezentatív mintáján kapott adatokkal (Paksi-MagiDemetrovics 2015), azt láthatjuk, hogy a diákok körében azonosított problémás játékosok aránya $(2,1 \%)$ több mint két és félszerese a felnőtt népességben található, hasonló kockázatú csoportnak $(0,8 \%)$.

Paksi és munkatársai eredményei szerint a szerencsejáték-használat már viszonylag fiatal korban megjelenik, és 18 éves korig exponenciálisan növekszik a szerencsejátékkal való kapcsolatba kerülés esélye (Paksi-Magi-Demetrovics 2016) (1. ábra).

Ezek az eredmények, valamint a 7-14. évfolyamosok körében az első játéktevékenység ideje és a PGSI pontszám között mutatkozó szignifikáns negatív korreláció (PGSI korr: -0,114; sig < 0,001) alátámasztják a szerencsejáték-használatra irányuló beavatkozások minél korábbra, fiatal, illetve fiatal felnőtt korra való időzítését, valamint végső célkitüzéseként az első szerencsejáték-használat időpontjának kitolását, a fiatal korosztályok játéktevékenységben való érintettségének csökkentését.

\section{Célok}

Egy humán szolgáltatás tervezése során meghatározó a beavatkozás tényalapúsága, amely jelenti egyrészt az alkalmazott célok és módszerek szakirodalmi megalapozását, a célközönség szükségleteinek megismerését, valamint a kockázati és megóvó tényezők empirikus azonosítását. 
A tanulmány célja a szerencsejáték-tevékenység kockázatainak csökkentésére irányuló, eredményesnek bizonyult univerzális prevenciós programok ${ }^{2}$ és jellemzőik azonosítása a fiatal és fiatal felnőtt (14-24 éves) populáció körében. A tanulmányban röviden bemutatásra kerülnek a programok, hangsúlyt fektetve a programleírások alapján azonosítható, eredményesnek mutatkozó célokra és módszerekre. Bár a nemzetközi szakirodalomban találunk az elmúlt évekből hasonló tematikájú összefoglalókat (pl. Gooding-Tarrier 2009; Ladouceur-Goulet-Vitaro 2013), jelen áttekintés a felölelt időszak és a vizsgálati fókuszok tekintetében is valamelyest eltér azoktól: jelen elemzés hangsúlyt fektet a programok végső célváltozójának mérésére és az abban tapasztalt elmozdulásokra.

\section{Módszer}

\section{A cikkek azonositásának módszere}

Online adatbázisokat felhasználva (PsychInfo, PubMed, ScienceDirect), kereső algoritmus (gambl* AND [prevention OR intervention]AND [effectiveness OR efficacy OR evaluation]) kialakításával azonosítottuk a téma releváns szakirodalmát. A találatokat leszükítettük az 1995 és 2015 között megjelent, angol nyelvü³ lektorált publikációkra.

A kereséseket a publikációk teljes szövegében (cím, absztrakt, kulcsszavak, föszöveg) végeztük. A vizsgált adatbázisok találati aránya a 1. táblázatban található.

1. táblázat: A témával foglalkozó írások száma a vizsgált adatbázisokban

\begin{tabular}{lc}
\hline Adatbázisok & Találatok száma $(\mathrm{db})$ \\
\hline PsychInfo & 2761 \\
ScienceDirect & 2142 \\
PubMed & 388 \\
\hline Összesen & 5291 \\
\hline
\end{tabular}

A duplikációszűrés (EndNote X6) után a végleges találati szám 4846 lett.

A cikkek további szelektálásához az alábbi hierarchikus szempontrendszert határoztuk meg:

1. Relevancia: az értékelt beavatkozás célcsoportja 14 és 24 év közötti fiatalokra vagy azok valamely alcsoportjára (is) irányul;

2. Empíria: empirikus (kvantitatív vagy kvalitatív) eredményekre épülő eredeti közlemények. Kiszelektálásra kerültek:

2 Az általános/univerzális prevenciós programok szolgáltatásaikkal egy teljes populációt (országosan, helyi közösségekben, iskolában) céloznak meg annak érdekében, hogy a problémaviselkedés megjelenését megakadályozzák vagy késleltessék. Ezek a prevenciós beavatkozások nagyobb csoportok számára elérhetők és a rizikótényezőkre vonatkozó előzetes szürések nélkül igénybe vehetők. Ilyen intervenciók közé tartoznak pl. az iskolai vagy családi prevenciók.

3 A keresési beállítások ellenére néhány esetben a keresett időszakon kívüli, illetve nem angol nyelvű, de angol nyelvü összefoglalóval rendelkező írások is szerepeltek a keresőprogramok által kiadott találatok között. Ezeket kézi szűréssel kiszelektáltuk a találatok közül. 
a) a kizárólag teoretikus megközelítést alkalmazó vagy véleményeket, alapelveket megfogalmazó közlemények;

b) az értékelés nélküli programleírások;

c) a csak mások által lefolytatott kutatásokra épülő, nem eredeti közlemények.

3. Minőségः a kutatási elrendezés és az elemzési stratégia megfelelősége. Kiszelektálásra kerültek:

a) a kvantitatív tanulmányok esetében egy minimális mintaelemszámot (minimum 100 fős) és/vagy a reprezentatív, random minta követelményét nem teljesítő kutatások;

b) az előbbi kritériumnak nem eleget tevő kvantitatív kutatások kvalitatív kutatásként nem emelhetők be a vizsgált körbe.

Ezen szempontrendszer alapján a találatokat tovább szűkítettük, melynek eredményeit a 2. táblázat tartalmazza.

2. táblázat: A szakirodalmi áttekintés során a különböző szelekciós kritériumok mentén kiszelektált publikációk száma

\begin{tabular}{lc}
\hline Szelekciós kritériumok & Kiszelektált publikációk száma $(\mathrm{db})$ \\
\hline Relevancia & 4762 \\
Empíria & 62 \\
Minőség & 2 \\
\hline
\end{tabular}

A leírt szempontok mentén 20 olyan publikációt azonosítottunk, melyek a célpopulációban (is) végzett értékelt intervenciókkal kapcsolatos, megfelelő minőségü empirikus kutatási eredményeket mutatnak be. Ezek közül az univerzális/általános prevenciós beavatkozások körébe 9 tanulmány sorolható, ezek mindegyike iskolai prevenciós programmal foglalkozott. 2 tanulmány ugyanazon program 2 változatát értékeli, így összesen 8 értékelt iskolai színtéren zajló, szerencsejáték-prevenciós program került az összefoglalóba.

Bár a kizárólag mások empirikus kutatásainak eredményeit összegző publikációkat nem vontuk be a szemlézett írások körébe, így a témában mások által készített összefoglalók sem képezik részét áttekintésünknek, ugyanakkor a témában készült korábbi áttekintések közül Ladouceur, Goulet és Vitaro (2013) szisztematikus irodalomfeldolgozásának módszertanát és ajánlásait felhasználjuk az általunk szemlézett irodalom bemutatása során $^{4}$

\section{A nemzetközi szakirodalomban fellelt, értékelt, általános prevenciós programok értékelésének módja}

A cikkeket részben - Ladouceurhez és munkatársaihoz hasonlóan (Ladouceur-GouletVitaro 2013) - az egyesült államokbeli Társaság a Prevenció-Kutatásért (Society for

4 Ugyan az említett tanulmány tematikája nagymértékű átfedést mutat jelen tanulmány metodikájával, az általunk alkalmazott kritériumok, valamint a vizsgált kimeneti változók több ponton eltérnek a korábban készített összefoglalóétól. 
Prevention Research, SPR) által javasolt öt szempont mentén (Flay et al. 2005) értékeljük. Az SPR két általános célt határozott meg, amihez a kritériumait igazította: A) a tapasztalt változások megfelelnek-e a program célkitűzéseinek, B) a tapasztalt változások az intervenció hatására jöttek-e létre. A két cél vizsgálatára öt kritériumot jelöl meg, melyek mentén minden tanulmány értékelése $0-2$ közötti értéket vehet fel.

Az öt kritérium és az annak való megfelelés osztályozása a következő (Flay et al. 2005):

I. Elméleti megalapozottság

(0) a program elméleti háttérre nem hivatkozik

(1) a program elméleti háttere implikált

(2) a program elméleti háttere expliciten bemutatott

II. Kutatási design

(0) nem kísérleti elrendezés (pl. nincs kontrollcsoport)

(1) kvázikísérleti elrendezés (pl. nincs randomizáció)

(2) kísérleti elrendezés (randomizált csoportba sorolás)

III. Alkalmazott méröeszközök pszichometriai mutatói

(0) a mérőeszközök pszichometriai mutatói nem megfelelőek

(1) legalább egy mérőeszköz pszichometriai mutatói megfelelőek

(2) minden alkalmazott mérőeszköz pszichometriai mutatói megfelelőek

IV. Utánkövetés

(0) nincs utánkövetés

(1) rövid távú utánkövetés (6 hónap vagy kevesebb idő után)

(2) hosszú távú utánkövetés (6 hónapnál hosszabb idő után)

V. Megismételt vizsgálat (replikáció)

(0) nincs megismételt vizsgálat

(1) a megismételt vizsgálat nem magas minőségű (lásd a II. szempontot)

(2) a megismételt vizsgálat magas minőségű (lásd a II. szempontot)

A szerencsejáték-magatartás interveniálásának tényalapú tervezése szempontjából meghatározó, hogy a célok szakirodalmi megalapozása során olyan értékelésekre támaszkodunk-e, melyek empirikusan vizsgálják a beavatkozás hatását a végső célváltozóra, vagy olyanokra, melyek csak a közbülső változók és a végső célváltozó közötti teoretikus (esetleg csak feltételezett) kapcsolat alapján vélelmezik a közbülső változóban mért elmozdulás alapján a szerencsejáték-használat változását. Jelen tanulmány során ezt - a prevenciós célváltozók tervezése szempontjából meghatározó - szempontot érvényesítve az SPR által javasolt öt szempontot a következő értékelési dimenzióval egészítettük ki:

VI. Végsö célváltozó tekintetében vizsgál-e változást

(0) nem vizsgálja a végső célváltozó változásait

(1) a kutatási design lehetőséget ad rá, de nem vizsgálja a végső célváltozó változásait

(2) vizsgálja is a végső célváltozó változásait

\section{Eredmények}

A publikációk fentiekben bemutatott hat szempont mentén való értékelését a 3, táblázat tartalmazza. 
3. táblázat: Az általános prevencióval foglalkozó publikációk értékelése az $\mathrm{SPR}+1$ értékelési kritériumok mentén

\begin{tabular}{|c|c|c|c|c|c|c|}
\hline Forrás & 岕 & 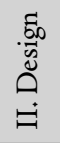 & 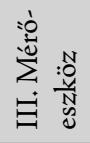 & 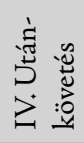 & 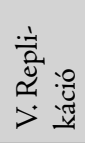 & 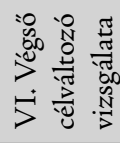 \\
\hline Donati-Primi-Chiesi 2014 & 1 & 2 & 2 & 2 & 0 & 2 \\
\hline Ferland-Ladouceur-Vitaro 2002 & 2 & 2 & 2 & 0 & 0 & 0 \\
\hline Ladouceur-Ferland-Vitaro 2004 & 2 & 2 & 2 & 0 & 0 & 0 \\
\hline Ladouceur et al. 2005 & 2 & 1 & 2 & 0 & 0 & 0 \\
\hline Taylor-Hillyard 2009 & 1 & 0 & 2 & 0 & 0 & 1 \\
\hline Turner et al. 2008 & 2 & 2 & 2 & 0 & 0 & 2 \\
\hline Turner-Macdonald-Somerset 2008 & 2 & 2 & 2 & 0 & 0 & 1 \\
\hline Walther-Hanewinkel-Morgenstern 2013 & 0 & 2 & 2 & 0 & 0 & 2 \\
\hline Williams-Wood-Currie 2010 & 1 & 2 & 2 & 0 & 0 & 2 \\
\hline
\end{tabular}

A z alkalmazott mérőeszközök pszichometriai mutatói megfelelőek, a kutatások többsége randomizált mintát alkalmazott, ugyanakkor az elméleti megalapozottság tekintetében meglehetős heterogenitás tapasztalható, s a programok értékelése során - egy tanulmány kivételével - nincs utánkövetés és megismételt vizsgálat.

\section{$A z$ általános prevenciós beavatkozások értékelésének bemutatása}

\section{Integrált intervenció}

Donati és munkatársai egy integrált intervenciós program preventív hatását vizsgálták a szerencsejátékkal kapcsolatos tudás és tévbitek, a szerencsejátékkal kapcsolatos gazdasági percepciók és a babonás gondolkodás módosításán keresztül a szerencsejáték-használatra nézve (Donati-Primi-Chiesi 2014).

Randomizált klinikai vizsgálat során 181 olasz serdülő 2 csoportját hasonlították össze (145 fó a kísérleti csoportban, 36 fó a kontrollcsoportban). Az első adatgyüjtést az intervenció előtt 2 héttel, a másodikat az intervenció után 1 héttel, az utánkövetéses adatgyüjtést pedig ezt követően 6 hónappal folytatták le. A szerencsejáték-használat mintázatában történő változások azonosításához szükséges adatokat csak a preteszt és az utánkövetéses adatfelvétel során gyüjtötték. A használt eszközök validitását és reliabilitását korábbi vizsgálatok támasztják alá, a vizsgálat során tapasztalt pszichometriai jellemzőket a tanulmány nem mutatja be.

Eredményeik szerint az intervenció a tévhitek kivételével minden vizsgált változó esetében statisztikailag jelentős változást indukált mind a problémamentes, mind a magas kockázatú játékosok körében, míg a tévhitekkel kapcsolatban csak a problémamentes serdülők körében tudtak hasonló eredményeket kimutatni, melyek időbeli stabilitást mutattak. Az interveniált csoportban mind a szerencsejátékosok, mind a magas kockázatú játékosok aránya jelentősen csökkent. 
A „Lucky” cimü videoalapú prevenciós program

A „Lucky” címü 20 perces kisfilmet speciálisan a szerencsejátékkal kapcsolatos tudás és tévbitek módositására fejlesztették ki. A videó egy Lucky nevü bohóc történetein keresztül a korai serdülőkorú és fiatalabb gyerekek számára érthető módon mutatja be a szerencsejátékhoz kapcsolódó tévhitek valótlanságát. Teoretikus hátterét Langer (1975) „a kontroll illúziója” elmélete adja. Ez alapján Ladouceur (1994) azt feltételezi, hogy a szerencsejátékosok nem veszik figyelembe a különálló játszmák egyediségét, így egy adott fogadás nyerési esélyeinek kiszámítását a korábbi fogadások eredményeire alapozzák. Az elmélet alapján a szerzők úgy gondolják, hogy a személyek szerencsejátékkal kapcsolatos gondolatainak megváltoztatásán keresztül a szerencsejáték-használat is módosítható. A program hatását több felmérés is vizsgálta.

Ferland és munkatársai a videó francia nyelvű változatát alkalmazva összesen 424 kanadai 11-15 év közötti diák körében 4 elrendezés eredményeit hasonlították össze: 1) csak a videó bemutatása, 2) szerencsejátékkal kapcsolatos előadás és tevékenységek, 3) a kettő együtt, 4) kontrollcsoport (Ferland-Ladouceur-Vitaro 2002). A randomizálás osztályszinten történt. A résztvevők a szerzők által fejlesztett szerencsejátékkal kapcsolatos tudást és tévhiteket mérő kérdőívet egy héttel az intervenciók előtt, majd az intervenciót követően ismét kitöltötték. A mérőeszköz bemutatott pszichometriai jellemzői megfelelőek. Konkrétan a szerencsejátékkal kapcsolatos viselkedésváltozást nem vizsgálták.

A vizsgálat eredményei szerint a videó már önmagában is jelentős mértékben növelte a diákok tudását és csökkentette tévhiteiket, előadással és egyéb tevékenységekkel kiegészítve pedig még nagyobb mértékủ volt a hatás.

Ladouceur és munkatársai a videó angol nyelvű változatával végeztek hasonló vizsgálatot. Összesen 4 iskolából, iskolák szintjén véletlenszerűen soroltak be 506 fó 12 és 15 év közötti diákot 2 kísérleti elrendezésbe: 1) a videó bemutatása, 2) kontrollcsoport (Ladoucer et al. 2004). Az elért hatás mértékét a Ferland és munkatársai által használt kérdőív segítségével vizsgálták, melynek mind a 16 tételére összesen 371 diák válaszolt (Ferland-Ladouceur-Vitaro 2002).

Eredményeik itt is arról számolnak be, hogy a program sikeresen növeli a diákok tudását és csökkenti tévhiteiket, azonban a vizsgálat alacsony hatásméreteit a szerzők is megemlítik.

\section{A „Szerencsejátékos történetek” címü videoalapú prevenciós program}

Hasonló módszerrel és elméleti háttérrel, de már egy másik videóval Ladouceur és munkatársai 3 iskolából összesen 568 diák körében végeztek vizsgálatot, mely a szerencsejáték-viselkedéssel kapcsolatban szintén nem fogalmazott meg hipotézist, és nem is vizsgálta a program arra gyakorolt hatását (Ladoucer et al. 2005). A „Szerencsejátékos történetek” („Gambling Stories”) című 20 perces videó a túlzott szerencsejáték-használat következményeit mutatja be serdülőket célzó stílusban.

Két elrendezést vizsgáltak: 1) videó bemutatása (361 fö), 2) kontrollcsoport (207 fö). A tanulmány nem nyújt információt az elrendezésekbe történő besorolás módjáról. 3 tényezőt vizsgáló, saját kialakítású, megfelelő mutatókkal rendelkező kérdőív segítségével mérték a megcélzott változásokat: 1) szerencsejátékkal kapcsolatos általános tudás, 2) túlzott szerencsejátékkal kapcsolatos tudás és 3) sztereotípiák. Az első kitöltés után a kísérleti csoport megnézte a videót, majd az intervenció után 1 hónappal ismét 
mindenki kitöltötte a kérdőívet.Eredményeik szerint a videó megtekintése jelentős mértékben javította a serdülők körében a szerencsejáték, a túlzott használat és negatív következményeinek észlelését, pontosabban értették az esély fogalmát. Bár konkrét szerencsejáték-használati viselkedést nem mértek, feltételezésük szerint az ismeretek módosításának feltételezhető az ilyen irányú hatása is.

"Ne játszd el a jövőnket” („Don't gamble away our future”) cimü program

Taylor és Hillyard (2009) egy együléses, 8-18 év közötti fiatalok számára kifejlesztett intervenció, a „Ne játszd el a jövőnket” („Don't gamble away our future”) címü program hatását vizsgálták, mely 3 célt tüzött ki maga elé: 1) a szerencsejátékkal kapcsolatos ismeretek bővítése, 2) tévhitek, valamint 3) a problémás és patológiás szerencsejáték-használók arányának csökkentése. Maga a program előadásból, különböző tevékenységekből és megbeszélésből állt, valamint a résztvevők kaptak egy CD-lemezt, mely a célokhoz kapcsolódó interaktív feladatokat tartalmaz.

Négy populáció 12 év feletti tagjainál, összesen 8455 fős kényelmi mintán vizsgálták a beavatkozás eredményességét kontrollcsoport nélkül: 1) általános iskolás diákok, 2) a középiskolai éveinek elején és 3) végén járó diákok, valamint 4) javítóintézeti növendékek. Az intervenció előtt és után minden diák kitöltött egy, a szerencsejáték-használathoz köthető kockázatokat mérő, az Illinois Institute for Addiction Recovery intézmény által fejlesztett és validált kérdőívet. Bár az intervenció előtti adatgyüjtés során a szerencsejáték-használat problémásságát is felmérték, az adott tanulmány a változást már nem vizsgálta, utalva arra, hogy ezt a kérdést egy későbbi, longitudinális kutatás keretében tervezik vizsgálni.

Minden csoport esetében jelentős fejlődést tapasztaltak, és szignifikánsan jobb eredményeket mutattak a szerencsejátékkal kapcsolatos tudás, illetve a kapcsolódó veszélyek tekintetében, legnagyobb változást az általános iskolás, míg a legalacsonyabb mértéküt a középiskolás éveik végén járó diákok körében tapasztaltak. Szintén jelentékenyen nagyobb változást mértek a fiúknál, mint a lányoknál. Fontos korlátja a vizsgálatnak, hogy a két mérés időben nagyon közel volt egymáshoz, és az utánkövetéses vizsgálat is várat még magára.

\section{Egyórás iskolai prevenciós program}

Turner és munkatársai szintén egy együléses program hatékonyságát vizsgálták, melynek céljai közé tartozott az érzelmi és kognitív tapasztalatok közötti kapcsolatok, valamint a véletlen esélyének jobb megértése (Turner et al. 2008). A 60 perces, Ajzen és Fishbein (1980) indokolt cselekvési elméletére (Theory of Reasoned Action) alapozott ${ }^{5}$ foglalkozás során a szerencsejáték és a véletlen természetéről, valamint a nyeréshez és vesztéshez társuló, esetlegesen problémás használathoz vezető érzelmek szerepéről esett szó. Ezenkívül a résztvevők különböző szerepjátékok segítségével saját élményt is szerezhettek a témákkal kapcsolatban, valamint különböző megküzdési technikákat is elsajátítottak.

Az elmélet szerint a cselekvési szándékot két fő tényező befolyásolja: az első az adott viselkedéssel kapcsolatos attitűd, az, hogy a cselekvő mit gondol az adott magatartás következményeiről, és ezeket a következményeket mennyire tartja kívánatosnak. A második faktor a szubjektív norma, mely a cselekvő számára releváns szereplők elvárásait, és az ezeknek való megfelelési szándékot takarja. Az elméletet azt feltételezi, hogy a fenti tényezők következményeképpen alakul ki a cselekvési szándék, és ez közvetlenül összefügg a tényleges cselekvéssel. Az elméletet a szerencsejáték-magatartással Evans $(2001,2003)$ hozta összefüggésbe. 
A kutatásba összesen 374 fó 5 . és 12 . évfolyamba járó diákot vontak be, akiket két randomizált csoportba soroltak: 1) kísérleti csoport 212 fővel és 2) kontrollcsoport 162 fővel. Az első adatfelvétel egy héttel a beavatkozást megelőzően történt, majd 2 hónap múlva megismételték. Az önbeszámolós kérdőív-battéria összesen 6 különböző, megfelelő pszichometriai jellemzőkkel rendelkező skálából állt, mely a következő változókat célozta meg: véletlennel és szerencsével kapcsolatos ismeretek, szerencsejáték-használati jellemzők, tevékenységpreferencia és megküzdés.

Eredményeik szerint ugyan a program statisztikailag jelentős mértékben javított a véletlennel kapcsolatos ismereteken, azonban elhanyagolható hatásmérettel. A többi vizsgált mutató esetében még ezt az alacsony erejü eltérést sem sikerült kimutatniuk.

Órarendi keretbe épitett, kurrikulum jellegü szerencsejáték-prevenció

Turner, Macdonald és Somerset (2008) többek között a fentebb is említett, korábbi vizsgálataik eredményeire alapozva (Turner et al. 2008) már egy kibővített tartalmú, további célokat is maga elé tűző, egy jelentősen hosszabb (6+1 alkalmas) programot alakítottak ki, és vizsgálták annak eredményességét. A módosított program teoretikus hátterét itt Ajzen és Fishbein (1980) indokolt cselekvési elmélete mellett Bandura $(1977,1986)$ kognitív énhatékonyság elmélete, valamint Evans (2001, 2003) társas beoltás prevenciós modellje adta. Alapvetően 3 tartalmi elem köré csoportosulnak a foglalkozások, amelyek mentén a program segítségével változást kívántak indukálni: 1) véletlennel kapcsolatos ismeretek, 2) megküzdési és életvezetési képességek, 3) problémás viselkedés és indokolatlan kockázatok elkerülése tudatosság és önmonitorozás segítségével. A program elemeit a hagyományos oktatási rend kereteibe illesztették.

A program hatásvizsgálatát 15-18 éves diákok körében végezték, 101 fővel a kísérleti csoportban és 100 fövel a kontrollcsoportban az iskolák szintjén random módon besorolva. A változásokat validált skálák segítségével mérték a következő változók mentén: szerencsejáték-használati jellemzők, megküzdés, észlelt kontroll és tudatosság, perspektíva megtartása, társas források, humor és szervezettség, valamint a megküzdési stílus megtartásának képessége. A kísérleti csoport esetében a battéria kitöltésére elöször az intervenció előtt egy héttel került sor, majd az átlagosan 6-7 hetet igénybe vevő program után 4-5 héttel megismételték. A kontrollcsoport esetében az adatfelvételt 10-12 héttel később ismételték meg.

Eredményeik azt mutatták, hogy az intervenció jelentős mértékben növelte a véletlennel, az önmonitorozással és a megküzdéssel kapcsolatos ismereteket a kontrollcsoporthoz képest. A veszélyeztetett csoportoknál tapasztalt közepes és erős hatásméret-mutatók a tudatosság, az önmonitorozás és a véletlennel kapcsolatos ismeretek esetében az intervenció alkalmazhatóságát jelzik, azonban a megküzdés esetében nem találtak jelentős különbséget. Bár a szerencsejáték-használat mintázatát mérték, annak választott formája, egy kizárólag élet- és éves prevalencia-mutatókat tartalmazó kérdőív alkalmazása nem nyújtott lehetőséget a viselkedéses változás kimutatására.

\section{Szerencsejáték-prevenció serdülöknek}

Walther és munkatársai vizsgálata jelen összefoglalóban az egyetlen, amit Európában végeztek (Walther-Hanewinkel-Morgenstern 2013). Egy serdülők számára kidolgozott, 4 alkalmas, média alapú iskolai prevenciós program hatását vizsgálták, melynek egyik célja a szerencsejátékkal kapcsolatos tudás növelése, valamint az attitüdök és a viselke- 
dés módosítása volt. A program a szerencsejáték mellett az internethasználattal, online kommunikációval és számítógépes játékokkal is foglalkozik. A szerencsejátékot tárgyaló ülés interaktív feladatokat (érme feldobása, saját élmény), a patológiás szerencsejátékhasználat tüneteinek átbeszélését, valamint a különböző játékok jellemzőinek bemutatását tartalmazza.

A vizsgálatban 80 iskola összesen 2109 fó 10-15 éves diákját vonták be, mintavételi egységük az osztály volt. A részvevőket az iskolák szintjén, iskolatípus szerint rétegezve, véletlenszerüen 2 csoportba sorolták: 1) kísérleti csoport 888 fövel és 2) kontrollcsoport 1221 fővel. Az adatokat először az intervenció elött gyüjtötték, majd az ezt követő 3 hónap során hajtották végre a programot a kísérleti csoportba sorolt iskolákban. Az adatgyüjtés második köre az intervenció befejezését követően 3 hónappal történt. A szerencsejáték-használat életprevalenciáját és aktuális használatának gyakoriságát, valamint a szerencsejátékkal kapcsolatos attitüdöket és ismereteket mérték. Az alkalmazott skálák jellemzői elfogadhatók.

Eredményeik azt mutatják, hogy a program jelentősen javította a résztvevők szerencsejátékkal kapcsolatos ismereteit és attitüdjeit, valamint kisebb mértékben, de még mindig szignifikánsan csökkentette az aktuális szerencsejáték-használatot a kontrollcsoporthoz képest.

\section{"Leosztott Lapok” („Stacked Deck”) iskolai prevenciós program}

A „Leosztott Lapok” („Stacked Deck”) iskolai prevenciós program 5-6 interaktív foglalkozásból áll, célja a problémás szerencsejáték-használat kialakulásának megelözése, valamint olyan életvezetési készségek kialakítása, amelyek segítségével „okos játékos”-ként a fiatalok megfelelő döntéseket tudnak hozni a jövőben (Williams-Wood-Currie 2010). A program során a résztvevők információt kapnak a szerencsejátékok történetéről, a valós esélyekről, a kapcsolódó tévhitekről, a problémás szerencsejáték-használat rizikófaktorairól, jeleiről és okairól, valamint elsajátítják a megfelelő döntéshozatal és problémamegoldás képességeit. A szerzők feltételezik, hogy a program hatására más kockázati magatartások (pl. szerhasználat) is megváltoznak.

Tíz kanadai iskola 949 fö 9-12. évfolyamos diákjának bevonásával végezték el a program hatásvizsgálatát. Kontrollcsoportként 4 másik iskola 291 diákja körében vették fel az adatokat. $\mathrm{A} z$ iskolák kísérleti elrendezésbe történő besorolása random módon történt, a kontrollcsoportba sorolt iskolák a vizsgálat után szintén részt vehettek a programban. Az első adatgyüjtés a kísérleti csoport esetében az első foglalkozás elején történt, míg a második adatfelvétel átlagosan 4,1 hónappal az intervenció után. A problémás szerencsejáték-használatot a DSM-IV-Multiple Response-Juvenile (DSM-IV-MR-J, Fisher 2000) kérdőívvel mérték, míg a szerencsejáték-használat mintázódását, az attitüdöket, általános ismereteket, tudatosságot és ellenállást, döntéshozatali és problémamegoldó képességeket, valamint a magas kockázatú tevékenységekben való részvételt összesen 43 (témánként 2-10) kérdéssel vizsgálták mindkét esetben, melyek megfelelő pszichometriai jellemzőkkel bírtak.

Eredményeik szerint az intervenció jelentős mértékben módosította a szerencsejáték iránti attitűdöket, növelte az ismereteket általában és a problémás szerencsejáték-használattal kapcsolatban is, ellenállóbbakká váltak a tévhitekkel szemben, javultak a döntéshozatali és problémamegoldó képességeik, valamint csökkent a problémamentes és a problémás szerencsejáték-használat is. Egyedül az egyéb, szintén magas kockázatú tevé- 
kenységekben való részvétel esetében nem értek el statisztikailag jelentős pozitív változást.

\section{Az eredmények összefoglalása}

A vizsgált programok közül mind a 8 fogalmazott meg a szerencsejáték-magatartás vonatkozásában (is) céltételezéseket: 6 tanulmány által bemutatott 5 program kívánt változást elérni általában a szerencsejáték-viselkedésssel kapcsolatban (Ferland-Ladouceur-Vitaro 2002; Ladouceur-Ferland-Vitaro 2004; Ladouceur et al. 2005; Turner-MacdonaldSomerset 2008; Walther-Hanewinkel-Morgenstern 2013; Williams-Wood-Currie 2010), illetve 3 program célozta meg specifikusan a problémás használat megelőzését (DonatiPrimi-Chiesi 2014; Taylor-Hillyard 2009; Williams-Wood-Currie 2010), mindegyikük mérte célváltozóik mentén a program hatására bekövetkező változásokat, s 3 esetben találtak kedvező irányú elmozdulást.

Az áttekintett tanulmányok alapján a vizsgált prevenciós beavatkozások körében három fö közbülső céltételezési típus azonosítható:

I. Ismeretátadással kapcsolatos, a szerencsejátékkal, illetve a problémás szerencsejáték-használattal kapcsolatos ismeretek bővitésére irányuló céltételezés mindegyik programban előfordult (Donati-Primi-Chiesi 2014; Ferland-Ladouceur-Vitaro 2002; Ladouceur-Ferland-Vitaro 2004; Ladouceur et al. 2005; Taylor-Hillyard 2009; Turner et al. 2008; Turner-Macdonald-Somerset 2008; Walther-HanewinkelMorgenstern 2013; Williams-Wood-Currie 2010).

II. Három program céljai között jelentek meg készségfejlesztéssel kapcsolatos céltételezések. Ezek közül két program a hatékonyabb megküzdési stratégiák kialakítására (Turner et al. 2008; Turner-Macdonald-Somerset 2008), míg egy program különbözö életvezetési készségek fejlesztésére irányult (Williams-Wood-Currie 2010).

III. Két program (Walther-Hanewinkel-Morgenstern 2013; Williams-Wood-Currie 2010) fogalmazott meg szerencsejáték iránti attitüdök befolyásolásával kapcsolatos céltételezéseket.

Három program esetében találtunk kedvező irányú elmozdulást a szerencsejátékmagatartás vonatkozásában. Az általuk alkalmazott közbülső célok azok, melyek a szerencsejáték tevékenység kockázatainak csökkentésére irányuló prevenciós tevékenység szakmai megalapozását jelentik. A beazonosított közbülső célváltozók összegzését a 4. táblázat tartalmazza.

Részletes programleírást mindössze egy tanulmány közölt (Williams-Wood-Currie 2010), így az itt bemutatott módszerek leírása nem feltétlenül tükrözi a programok teljes eszközrepertoárját. Emellett egy tanulmány kivételével mindegyikük több módszertani elem alkalmazását említette, s azoknak a hatását külön-külön nem vizsgálták, így nincs lehetőségünk egy-egy módszer eredményességének bemutatására.

A programok időtartamát tekintve négy program egyórás intervenciókat vizsgált (Ferland-Ladouceur-Vitaro 2002; Ladouceur-Ferland-Vitaro 2004; Ladouceur et al. 2005; Taylor-Hillyard 2009; Turner et al. 2008), s a másik 4 tanulmány pedig minimum 4 alkalomból álló programokkal foglalkozott (Donati-Primi-Chiesi 2014; TurnerMacdonald-Somerset 2008; Walther-Hanewinkel-Morgenstern 2013; Williams-WoodCurrie 2010). 
4. táblázat: A szerencsejáték-magatartással kapcsolatos céltételezések mentén kedvező irányú változást mutató programok közbülső célváltozói és azok elmozdulásai

\begin{tabular}{|c|c|c|}
\hline & Problémás szerencsejáték-használat & Általában a szerencsejáték-használat \\
\hline \multirow{6}{*}{ 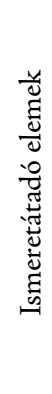 } & \multicolumn{2}{|c|}{ szerencsejátékkal kapcsolatos tudás } \\
\hline & $\begin{array}{l}\text { Donati-Primi-Chiesi 2014; Williams- } \\
\text { Wood-Currie } 2010\end{array}$ & $\begin{array}{l}\text { Walther-Hanewinkel-Morgenstern 2013; } \\
\text { Williams-Wood-Currie } 2010\end{array}$ \\
\hline & \multicolumn{2}{|c|}{ problémás szerencsejátékkal kapcsolatos tudás } \\
\hline & Williams-Wood-Currie 2010 & Williams-Wood-Currie 2010 \\
\hline & \multicolumn{2}{|c|}{ szerencsejátékkal kapcsolatos gazdasági percepciók } \\
\hline & \multicolumn{2}{|l|}{ Donati-Primi-Chiesi 2014} \\
\hline \multirow{4}{*}{ 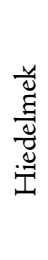 } & \multicolumn{2}{|c|}{ babonás gondolkodás } \\
\hline & \multicolumn{2}{|l|}{ Donati-Primi-Chiesi 2014} \\
\hline & \multicolumn{2}{|c|}{ szerencsejátékkal kapcsolatos tévhitek } \\
\hline & $\begin{array}{l}\text { Donati-Primi-Chiesi 2014*; Williams- } \\
\text { Wood-Currie } 2010\end{array}$ & Williams-Wood-Currie 2010 \\
\hline
\end{tabular}

szerencsejátékkal kapcsolatos attitüdök

Williams-Wood-Currie 2010

Walther-Hanewinkel-Morgenstern 2013;

Williams-Wood-Currie 2010

életvezetési (döntéshozatal és problémamegoldás) készségek

Williams-Wood-Currie 2010

Williams-Wood-Currie 2010

*csak problémamentes serdülőknél tapasztaltak változást

$\mathrm{Az}$ alkalmazott módszerek közül a programok többségében megjelentek frontális elemek, hét program tartalmazott elöadásokat (Donati-Primi-Chiesi 2014; FerlandLadouceur-Vitaro 2002; Ladouceur-Ferland-Vitaro 2004; Taylor-Hillyard 2009; Turner et al. 2008; Turner-Macdonald-Somerset 2008; Walther-Hanewinkel-Morgenstern 2013; Williams-Wood-Currie 2010), melyek az általános szerencsejátékkal kapcsolatos ismereteken felül esetenként kiterjedtek a problémás használat jellemzőire, kapcsolódó érzelmekre, illetve egyéb, megküzdéssel, tudatossággal és önmonitorozással kapcsolatos életvezetési stílusokra. Azonban a frontális módszerek önálló, kizárólagos előfordulása nem volt jellemző. Az interaktivitást megjelenítő módszerek között a következők kerültek megemlítésre:

- Öt program jelezte az előadások témájához kapcsolódó megbeszélések jelentőségét, többségük (négy) a többüléses programok közül került ki (Donati-Primi-Chiesi 2014; Ferland-Ladouceur-Vitaro 2002; Turner-Macdonald-Somerset 2008; WaltherHanewinkel-Morgenstern 2013; Williams-Wood-Currie 2010).

- Négy - egy kivétellel többüléses - program esetében említették a saját élményt nyújtó programelemek jelenlétét (Donati-Primi-Chiesi 2014; Walther-HanewinkelMorgenstern 2013; Williams-Wood-Currie 2010; Turner et al. 2008). Ezek rendszerint 
olyan véletlen eseményeket bemutató feladatok, amelyeken keresztül megtapasztalhatják a szerencsejátékok nyújtotta élményeket, illetve a valós nyerési- és vesztési esélyeket.

- Két program estében került említésre a különbözö készségek (megküzdési, illetve életvezetési) elsajátítását segitó technikák, interaktív gyakorlati feladatok alkalmazása (Turner et al. 2008; Williams-Wood-Currie 2010).

- Egy együléses program leírása tartalmazott otthoni interaktív feladatokat, amelyeket a résztvevők egy CD-lemez segítségével otthon, egyedül is el tudtak végezni (TaylorHillyard 2009).

- Szintén ez az együléses program nem specifikáltan említett egyéb aktív tevékenységeket, melyek pontos tartalmát nem ismertették (Taylor-Hillyard 2009). Összesen öt program alkalmazott videót, három egyalkalmas (Ferland-Ladouceur-Vitaro 2002; Ladouceur-Ferland-Vitaro 2004; Ladouceur et al. 2005), és két hosszabb program (Donati-Primi-Chiesi 2014; Williams-Wood-Currie 2010).

\section{Konklúzió}

Jelen tanulmány a szerencsejáték-tevékenység kockázatainak csökkentésére irányuló, a 14-24 éves populáció számára tervezett prevenciós tevékenység szakirodalmi megalapozása érdekében az 1995-2015 között publikált releváns nemzetközi szakirodalmat tekintette át a hatékony univerzális prevenciós elemek (célok és módszerek) azonosítása érdekében.

$\mathrm{A} z$ áttekintés eredményeként négy olyan iránymutatással szolgáló fő elemet (közbülső célt) sikerült azonosítani, melyek a szerencsejáték-magatartással, és/vagy a problémás szerencsejáték-használattal kapcsolatos céltételezések mentén kedvező irányú változást idézett elő: 1) ismeretátadás (problémás és általános szerencsejátékkal kapcsolatos tudás); 2) hiedelmek lebontása (babonás gondolkodás, tévhitek); 3) attitűdök befolyásolása; 4) készségfejlesztés (életvezetési, döntéshozatali, problémamegoldási készségek).

A beazonosított programok az ülések száma tekintetében nagyfokú heterogenitást mutattak.

Bár a módszerek szempontjából a frontális előadások tekinthetők dominánsnak, ugyanakkor az áttekintett programok mindegyike kiegészül interaktív (beszélgetés, saját élmény, készségfejlesztés) és/vagy multimédiás (CD-lemez, videó) elemekkel, mely a komplex eszköztárral rendelkező intervenciók alkalmazásának irányába mutat.

Jelen elemzés korlátja egyrészt, hogy részletes programleírásokkal mindössze egy intervenció esetében találkozhattunk, illetve az általunk fellelt tanulmányokban az egyes alkalmazott módszerek és a (problémás) szerencsejáték-használat változása mint végső célváltozó közötti összefüggéseket nem tudtuk vizsgálni. Az utánkövetéses vizsgálatok szintén hiányoznak, mindössze egy program esetében találtunk erre vonatkozó adatokat. Ugyan elemzésünk csak publikált értékelő vizsgálatokra korlátozódik, de a témában korábban megjelent, és jelen tanulmány vizsgálati periódusával részben átfedést mutató összefoglalók által beazonosított programok elemzésünk érvényességét támasztják alá. 


\section{IRODALOM}

Ajzen, I. \& Fishbein, M. (1980) Understanding Attitudes and Predicting Social Behavior. Englewood Cliffs (NJ), Prentice-Hall.

American Psychiatric Association (2000) Diagnostic and Statistical Manual of Mental Disorders. (4th Rev. ed.) Washington DC, American Psychiatric Association.

American Psychiatric Association (2013) Diagnostic and Statistical Manual of Mental Disorders. (5th ed.) Washington DC, American Psychiatric Association.

Bandura, A. (1977) Social Learning Theory. Englewood Cliffs (NJ), Prentice-Hall.

Bandura, A. (1986) Social Foundations of Thought and Action: A Social Cognitive Theory. Englewood Cliffs (NJ), Prentice-Hall.

Demetrovics Zs. (2007) Az addiktológia alapfogalmai. In: Demetrovics Zs. (ed.) Az addiktológia alapjai I. Eötvös Kiadó, Budapest. pp. 27-46.

Demetrovics Zs., Paksi B., Magi A. \& Felvinczi K. (2016) Egyes viselkedési addikciók elterjedtsége és társadalmi mintázódása a magyarországi felnőtt népesség körében. In: Vargha A. (ed.) Múlt és jelen összeér. A Magyar Pszichológiai Társaság XXV. Jubileumi Országos Tudományos Nagygyülése. Kivonatkötet. Budapest, MPT. pp. 80-81. http:// mipszi.hu/sites/default/files/mpt_ngy2016_kivonatkotet_0509.pdf [Letöltve: 2019.09. 01.]

Donati, M. A., Primi, C. \& Chiesi, F. (2014) Prevention of Problematic Gambling Behavior among Adolescents: Testing the Efficacy of an Integrative Intervention. Journal of Gambling Studies, Vol. 30. No. 4. pp. 803-818.

EMCDDA (2011) European Drug Prevention Quality Standards: A Manual for Prevention Professionals. Lisszabon, European Monitoring Centre for Drugs and Drug Addiction (EMCDDA).

Evans, R. I. (2001) Social Influences in Etiology, Prevention of Smoking, Other Health Threatening Behaviours in Children and Adolescents. In: A. Baum, T. A. Revenson, J. E. Singer (eds) Handbook of Health Psychology. Mahwah (NJ), Earlbaum. pp. 459-468.

Evans, R. I. (2003) Some Theoretical Models and Constructs Generic to Substance Abuse Prevention Programs for Adolescents: Possible Relevance and Limitations for Problem Gambling. Journal of Gambling Studies, Vol. 19. No. 3. pp. 287-302.

Ferland, F., Ladouceur, R. \& Vitaro, F. (2002) Prevention of Problem Gambling: Modifying Misconceptions and Increasing Knowledge. Journal of Gambling Studies, Vol. 18. No. 1. pp. 19-29.

Fisher, S. (2000) Developing the DSM-IV-MR-J Criteria to Identify Adolescent Problem Gambling in Non-clinical Populations. Journal of Gambling Studies, Vol. 16. Nos 2-3. pp. 253-273.

Flay, B. R., Biglan, A., Boruch, R. F., Castro, F. G., Gottraredson, D., Kellam, S., Moscicki, E. K., Schinke, S., Valentine, J. C. \& Ji, P. (2005) Standards of Evidence: Criteria for Efficacy, Effectiveness and Dissemination. Prevention Science, Vol. 6. No. 3. pp. 151-175.

Gooding, P. \& TArrier, N. (2009) A Systematic Review and Meta-analysis of CognitiveBehavioural Interventions to Reduce Problem Gambling: Hedging Our Bets? Behaviour Research and Therapy, Vol. 47. No. 7. pp. 592-607.

Gyollai Á., Urbán R., Farkas J., Kun B., Kökönyei Gy., Eisinger A., Magi A. \& Demetrovics Zs. (2013) A Szerencsejáték Probléma Súlyossága Kérdőív magyar változatának (PGSI-HU) bemutatása. Psychiatria Hungarica, Vol. 28. No. 3. pp. 274-280. 
Ladouceur, R. (1994) La psychologie des jeux de hasard et d'argent: aspects fondamentaux et cliniques. Loisir et société, 17. pp. 215-234.

Ladouceur, R., Ferland, F. \& Vitaro, F. (2004) Prevention of Problem Gambling: Modifying Misconceptions and Increasing Knowledge among Canadian Youths. Journal of Primary Prevention, Vol. 25. No. 3. pp. 329-335.

Ladouceur, R., Ferland, F., Vitaro, F. \& Pelletier, O. (2005) Modifying Youths' Perception toward Pathological Gamblers. Addictive Behaviors, Vol. 30. No. 2. pp. 351354.

Ladouceur, R., Goulet, A. \& Vitaro, F. (2013) Prevention Programmes for Youth Gambling: A Review of the Empirical Evidence. International Gambling Studies, Vol. 13. No. 2. pp. 141-159.

Langer, E. (1975) The Illusion of Control. Journal of Personality and Social Psychology, Vol. 32. pp. 311-328.

Mrazek, P. J. \& Haggerty, R. J. (1994, eds) Reducing Risks for Mental Disorders: Frontiers for Preventive Intervention Research. Washington DC, Institute of Medicine, National Academy Press.

Paksi B., Magi A. \& Demetrovics Zs. (2015) Estimating the Risk Potential of Hungarian Gambling Products. 2nd International Conference on Behavioral Addictions. Budapest, Hungary March 16-18, 2015. Journal of Behavioral Addictions, V. 4. Supplement 1. pp. 57-58.

Paksi B., Magi A. \& Demetrovics Zs. (2016) A szerencsejáték, illetve a problémás szerencsejáték használat kockázatai, a kockázatok társadalmi/demográfiai mintázódása és azok prevencióval kapcsolatos folyományai a serdülő korosztályban. In: VARGHA A. (ed.) Múlt és jelen összeér. A Magyar Pszichológiai Társaság XXV. Jubileumi Országos Tudományos Nagygyülése. Kivonatkötet. Budapest, MPT. pp. 80-81. http://mipszi.hu/sites/ default/files/mpt_ngy2016_kivonatkotet_0509.pdf [Letöltve: 2019.09. 01.]

Taylor, L. M. \& Hillyard, P. (2009) Gambling Awareness for Youth: An Analysis of the "Don't Gamble Away Our Future ${ }^{\mathrm{Tn}}$ " Program. International Journal of Mental Health and Addiction, Vol. 7. No. 1. pp. 250-261.

Turner, N., Macdonald, J., Bartoshuk, M. \& Zangeneh, M. (2008) The Evaluation of 1-H Prevention Program for Problem Gambling. International Journal of Mental Health and Addiction, Vol. 6. No. 2. pp. 238-243.

Turner, N. E., Macdonald, J. \& Somerset, M. (2008) Life Skills, Mathematical Reasoning and Critical Thinking: A Curriculum for the Prevention of Problem Gambling. Journal of Gambling Studies, Vol. 24. No. 3. pp. 367-380.

Walther, B., Hanewinkel, R. \& Morgenstern, M. (2013) Short-term Effects of a School-based Program on Gambling Prevention in Adolescents. Journal of Adolescent Health, Vol. 52. No. 5. pp. 599-605.

Williams, R. J., Wood, R. T. \& Currie, S. R. (2010) Stacked Deck: An Effective, Schoolbased Program for the Prevention of Problem Gambling. Journal of Primary Prevention, Vol. 31. No. 3. pp. 109-125.

World Health Organization (1992) The ICD-10 Classification of Mental and Behavioural Disorders: Clinical Descriptions and Diagnostic Guidelines. Geneva, World Health Organization.

A cikk a Creative Commons Attribution 4.0 International License (https://creativecommons.org/licenses/ by/4.0/) feltételei szerint publikált Open Access közlemény, melynek szellemében a cikk bármilyen médiumban szabadon felhasználható, megosztható és újraközölhető, feltéve, hogy az eredeti szerző és a közlés helye, illetve a CC License linkje és az esetlegesen végrehajtott módosítások feltüntetésre kerülnek. (SID_1) 